\title{
A PROSA DE MÁRIO DE ANDRADE, POETA
}

\section{Nathalia de Aguiar Ferreira Campos*}

* nathaguiarcampos@gmail.com

Bolsista CAPES, Mestranda em Teoria da Literatura pelo Programa de Estudos Literários da Fale-UFMG com área de concentração em Literatura, história e
memória cultural (LHMC).

RESUMO: O presente texto explora a hipótese de que uma das ambições literárias do polígrafo Mário de Andrade teria sido uma obra de ficção em prosa nos moldes de um romance, malograda em projetos como Quatro pessoas (1938-1943). Discutem-se, ainda, outros momentos da produção em prosa do escritor com destaque para seu conjunto epistolográfico.

PALAVRAS-CHAVE: Mário de Andrade; prosa de poeta; prosa de ficção; prosaico; poético.
RESUMEN: Este texto explora la hipótesis de que una de las ambiciones literarias del polígrafo Mário de Andrade habría sido una obra de ficción en prosa en los moldes de un romance, malograda en proyectos como Cuatro personas (1938-1943). Son todavía discutidos otros momentos de la producción en prosa del escritor, con destaque para su conjunto epistolográfico.

PALABRAS CLAVE: Mário de Andrade; prosa de poeta prosa de ficción; prosaico; poético. 


\section{MÁRIO DE ANDRADE: UM HOMEM CINDIDO}

“[...] pra meu espírito vale mais lançar uma biblioteca popular ou fazer uma pesquisa etnográfica do que escrever uma obra-prima."

(Mário de Andrade em carta de 29 de outubro de 1936 a Otávio Dias Leite)

Mário de Andrade foi um homem e um escritor crivado, a olhos vistos, de muitas contradições. Entre elas, uma atinge também outros tantos escritores brasileiros modernistas através das décadas de 1920 a 1950: de um lado, a aspiração pela realização artística individual e, de outro, a necessidade do ganha-pão. Outra, que o particulariza, refere-se à sua militância cultural, difícil de conciliar com o exercício da literatura, e da literatura somente, frequentemente sacrificado ao longo da trajetória do escritor.

Para os escritores brasileiros ativos especialmente ao longo das décadas de 1930 a 1950, período, não por acaso, em que a doutrina do realismo socialista está em voga no país, o dilema consiste em lidar com a necessidade do ganha-pão e o compromisso com a escrita. O segmento vê-se, ainda, premido diante da demanda de militar tendo a literatura por instrumento, ou fazer da palavra uma arma. É imprescindível assinalar que, nesse momento, a neófita literatura brasileira ainda reclama, timidamente, uma maturidade estética e, sobretudo, a consolidação de um caráter próprio, que só poderá nascer em uma situação de independência das pressões externas por explicar e pensar o Brasil, suas contradições e arestas em nível histórico, social, político e cultural. A bem dizer, se o país ainda claudicava na superação do estatuto colonial, sendo a modernidade ainda um projeto longe da conclusão, como reivindicar uma literatura diferente, isto é, segura e livre? Defendo, por ora, a hipótese de que um país jovem, inteiramente por fazer, repleto de incoerências e indefinições, passava, em tal momento, por uma fase de decisiva transição, de modo que exigir que a literatura e todo o dispositivo literário ostentassem segurança e clareza de seu papel apresentava-se pouco razoável. Outra hipótese, a reforçar a primeira, pode ser extraída do pensamento do Machado de Assis crítico, em seu memorável texto "Instinto de nacionalidade”. Nele, o escritor denuncia a escassa prática de gêneros como filosofia, linguística, crítica histórica e alta política no Brasil, com, de outro lado, o farto cultivo do romance e da poesia lírica (ASSIS, 2000, p. 136), uma assimetria possivelmente reveladora da escassez de lugares de reflexão no país a respeito de temas formadores da cultura, em que está incluído o próprio Brasil. ${ }^{1}$ Assim, argumento que restava ao romance - estimado no Brasil como a forma literária por excelência, ou a própria literatura - a tarefa de meditar sobre o país, refletir a respeito de sua formação
1. Vale também ressaltar, aqui, que as chamadas disciplinas cientificas ainda não possuiam, ão nútida de deus limites. tăo nitida de seus limites. Academicamente, os saberes estavam mais intercambiados entre si e influenciavam-se mutuamente. As "incumbências" de uma ou outra disciplin desse modo, ainda confundem.

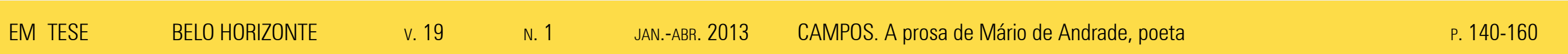


histórica, conjeturar os rumos futuros, além de apontar as feridas da sociedade.

Para Silviano Santiago, a necessidade de pensar o Brasil, de formar a identidade nacional e corrigir a realidade estorva assinaladamente a liberdade literária:

O escritor dos anos 1930, ao menosprezar os argumentos da interpretação modernista como sendo orientados pelo éthos cultural e ao fazer intervir a análise marxista na compreensão do processo histórico brasileiro, necessariamente pequena e tardia da imensa História da humanidade - o escritor dos anos 1930, repito, volta ao caminho trilhado por uma política universalista radical, agora culturalmente centrada no materialismo histórico. A essa análise recorre ele tanto para a avaliação do passado nacional, quanto para avançar um ideário utópico que deve pôr fim à injustiça econômica e social no país e no mundo. A produção artística deixa de ser fermento inaugural do multiculturalismo, a serviço da especulação política e da subversão estética, e passa a vir atrelada à crítica da estrutura econômica da sociedade (na época inspirada pelo realismo, soprado de todos os lados da América Latina pelos congressos de literatura de inspiração soviética). Ao se impor como teleológica, a estética de fundamento marxista reprime a imaginação do escritor e, ao mesmo tempo, aguça e redireciona radicalmente o seu olhar para o espetáculo miserável da realidade brasilei ra [...]. Afirma Antonio Candido que, na literatura dos anos
1930, "é marcante a preponderância do problema sobre o personagem” (SANTIAGO, 2004, p. 30-31. grifos meus).

O revolucionário em Mário de Andrade, por sua vez, toma a peito a necessidade inalienável de contribuir os novos rumos ao Brasil, de maneira a inseri-lo no rol das nações modernas e civilizadas. Para tanto, entende ser imprescindível, primeiro, "descobrir o Brasil" - este então ilustre desconhecido dos próprios brasileiros - pelo caminho da cultura, entrando em contato com as expressões populares, as variedades linguísticas, manifestações folclóricas e todo o rico patrimônio inexplorado do "continente" Brasil.

O projeto modernista de desbravamento do país - a viagem ao interior do Brasil - estava na base da aspiração estética dos modernos: engendrar uma arte e cultura que se relacionasse de forma desproblematizada com a tradição europeia ao mesmo tempo que ostentasse uma cor genuinamente e inconfundivelmente brasileira, para além dos estereótipos do exotismo e da barbárie. Do barroco mineiro, do carnaval carioca e do índio do Norte seria, pois, extraída essa quintessência. Mas, diante de uma ocupação tão nobre e absorvente, que espaço restava à expressão do escritor em Mário de Andrade?

Como dito, no que respeita o lugar do escritor na esfera pública, não é exagero afirmar que o homem de letras 
equilibra-se, como malabarista, entre salvaguardar a liberdade da escrita e as dificuldades de sobrevivência em um país onde as alternativas de trabalho para o escritor, sobretudo para o homem culto sem diploma superior, minguavam. Eram poucos os que podiam ostentar o título de "homens sem profissão", como Oswald de Andrade, que, tendo herdado vasta fortuna do pai, grande especulador urbano e vereador, pôde dedicar-se por inteiro à literatura e ao projeto vanguardista brasileiro de que foi protagonista. Os chamados "primos pobres”, protótipo encarnado, como nenhum outro, por Mário de Andrade, herdeiros de fortunas dilapidadas que conservaram de sua origem ilustre apenas o sobrenome, viam-se obrigados a exercer atividade remunerada no "mercado de trabalho intelectual” (MICELI, 1979, p. 118), em que seu rico capital cultural podia ser aproveitado: na vida acadêmica, no jornalismo ou no funcionalismo público. A cooptação dos segmentos da elite pensante pelas esferas do poder perpassa toda a história da intelectualidade brasileira na modernidade e tem exemplos proeminentes pelas décadas de 1930 1940: Carlos Drummond de Andrade é chefe de gabinete de Gustavo Capanema, então ministro da Educação; Mário de Andrade dirige o Departamento de Cultura do Município de São Paulo e integra o Partido Democrático; Graciliano Ramos, Erico Verissimo, Gilberto Freyre e Cecília Meireles escrevem para publicações governamentais durante o Estado
Lara Rezende e Rubem Braga, para os grandes jornais do Rio de Janeiro.

A proximidade do escritor com o aparelho do Estado cria, para o primeiro, a delicada problemática das concessões ideológicas: a aceitação de um cargo oficial significa, para muitos, trair suas convicções políticas e mais arraigados princípios e, sobretudo, o desvirtuamento de sua tarefa como escritor, ao assumir um papel - incômodo - que não é o de escrever. Silviano Santiago, em "O intelectual modernista revisitado”, salienta que Mário de Andrade mostrava-se amplamente consciente das implicações, para o homem de letras, de seu rebaixamento a funcionário público. Ao aceitar a proposta do então prefeito de São Paulo, Fábio Prado, em 1935, para dirigir o recém-criado Departamento de Cultura do Município de São Paulo, o homem que já havia se "suicidado" na década de 1920 por praticar a chamada "arte de ação”, o faz mais uma vez (SANTIAGO, 1989, p. 171).

Naturalmente, como embaixador da modernidade e autoridade estética entre seus contemporâneos, Mário sofre com o complexo do polígrafo, ou o acúmulo de funções do "intelectual total", cuja competência cultural abrange muitos domínios, "da literatura às belas-artes e à música, do folclore à etnografia e à história” (MICELI, 1979, p. 25-26). Contudo, não se cansou de reiterar que seu compromisso social vinha antes de sua realização como escritor (pelo menos, "da boca

\section{Ensino e Teoria}


para fora"), ainda que tal decisão, ao longo de toda a sua carreira, tenha sido fonte de conflito e de alguma frustração. Sua correspondência será o suporte em que o escritor em Mário de Andrade deitará, com grande entusiasmo, suas altas ambições para a literatura, que, não raro, se concretizam em projetos frustrados, como é o caso da ópera-coral inacabada Café, escrita entre 1933 e 1942, e de Quatro pessoas, tentativa de romance psicológico iniciada em 1938 e interrompida em 1943.

Neste breve texto, pretendo advogar a teoria de que escrever prosa de ficção, para o Mário de Andrade vindo do reino da poesia, corresponde a uma ambição por ampliar o raio de penetração de sua literatura, isto é, agradar o gosto de um grande público, indiferente a "literatices", e cuja recepção escapava ao controle do escritor. Tal compreensão - aparentemente simplista e ingênua no que concerne às motivações do poeta ao buscar o texto em prosa, e, nesse caso, a prosa de ficção - deve colocar-se como complemento às três premissas aventadas por Susan Sontag em seu ensaio "Uma prosa de poeta”, definidoras, na visão dela, do caráter da prosa sui generis produzida por poetas. Para inserir tal hipótese ao lado dessas premissas, elejo Mário de Andrade - dínamo, que transitou pelos ambientes de prosa e poesia e por vasta gama de gêneros de escrita com a inquietação de quem parecia ter a ambição de estar em todos os lugares, ou não deixar espaços potenciais inexplorados no âmbito da literatura e da cultura. O escritor, no entanto, pratica vastamente, além da poesia, a prosa jornalística e ensaística, de modo que a aventura pelas sendas da prosa de ficção parece ter sido relegado a segundo plano. Sempre em paralelo à sua atividade literária, praticou ainda a epistolografia como nenhum outro escritor brasileiro, constituindo um conjunto de textos que são hoje alvo de interesse que muitas vezes supera aquele despertado por sua produção propriamente literária.

A seguir, proponho também, oportunamente, algumas considerações sobre as tradicionais diferenças entre prosa e poesia - e em que medida estas se verificam na prática assim como uma análise de alguns momentos da prosa marioandradina - primeiro, de trechos de sua correspondência que subsidiam a hipótese de que Mário projetou uma obra de ficção em prosa nos moldes de um romance - sua pretendida obra-prima - que não se concretizou. Posteriormente, teço comentário sobre um seus romances, Quatro pessoas, e sobre a rapsódia Macunaíma, como modelares do vício de "explicar o Brasil”, que se coloca como obstáculo à experiência da ficção desbragada.

\section{PROSA DE POETA: UMA HIPÓTESE}

A leitura dos trabalhos em prosa dos grandes poetas russos do século XX, como os de Marina Tsvetáieva e Ossip 
Mandesltam, inspira à crítica Susan Sontag uma reflexão sobre as motivações do poeta para buscar, em um dado momento de sua trajetória literária, o texto em prosa. Sontag vê, ainda, traços idiossincráticos para a prosa escrita por poeta, que sintetiza em três: 1 ) a prosa de poeta tem como tema característico o "desenvolvimento da vocação de poeta" (SONTAG, 2005, p. 19); 2) "a prosa de poeta é, sobretudo sobre ser poeta" (SONTAG, 2005, p. 20); 3) "a prosa de poetas é caracteristicamente elegíaca, retrospectiva” (SONTAG 2005, p. 21).

Uma passagem breve por qualquer uma das correspondências pessoais de Mário de Andrade, hábil no entabulamento das chamadas "amizades epistolares", permite verificar os contornos atribuídos por Sontag à prosa de poeta, e além. A plataforma epistolar é vital para o escritor, da qual se serve para participar detalhes, curiosidades e anedotas de seu processo criativo - embora mais raramente o faça na expectativa de algum feedback, fosse comentário ou sugestão de reparo crítico da parte seu interlocutor sobre o trabalho que exibe (à exceção de quando se trata de Manuel Bandeira, "mestre" de Mário, e Carlos Drummond de Andrade, cuja assombrosa maturidade literária revela-se já em tenra idade); em geral, é ele quem se coloca como crítico soberano da produção de seus interlocutores e aproveita o diálogo epistolar para fazer militância artística e política.
Mário, em crítica intitulada "Dona Flor", publicada no Diário de notícias do Rio de Janeiro em 1940, declara ser o gênero epistolar "uma espécie de violão da literatura" (MORAES, 1997, p. 185). Com esta colocação, Mário - um epistológrafo compulsivo, cuja correspondência, além de vasta, é das mais ricas entre os acervos de escritores brasileiros - define a carta segundo a sua nobre potencialidade de oferecer aos homens de letras um lugar em que podem exercitar suas habilidades, apurar sua técnica e, sobretudo, refletir sobre o fazer literário. A imagem lúdica do instrumento musical, em cujo planger de cordas o escritor adestra seus dedos e persegue o apuro estético, remete a uma situação de descontração, ensaio, preparação. Na concepção de Mário, a carta estaria "em segundo plano", "como um exercício que os iniciantes em letras deveriam praticar antes de se aventurarem no 'piano' da criação literária”. Assim, o violão - brejeiro e popular - estaria para a carta, enquanto o piano - austero e erudito - para a literatura.

É de se esperar que o gênero epistolar comporte, em sua natureza própria, reflexão e autorreflexão. No caso da epistolografia dos homens de letras, então, a reflexão e a autorreflexão voltam-se, inúmeras vezes, para o "eu-que-escreve", para além do "eu-que-existe". $\mathrm{O}$ aspecto do intercâmbio intelectual, com o exercício de crítica literária, e as divagações sobre detalhes intrínsecos ao texto poético - escolha 
de vocábulos, comentários sobre temas ligados ao processo de renovação literária modernista etc. - ganham relevo, e, considerando que as correspondências de Mário de Andrade ostentam, em sua maioria, largo fôlego, tendo muitas vezes abrangido toda uma vida, é possível afirmar que o "desenvolvimento da vocação de poeta", ao lado da tematização do "ser poeta" - a dor e a delícia de sê-lo - é característica marcada dessa forma em prosa.

Em uma das faces da moeda, o poeta Mário de Andrade faz de suas cartas "complementos das obras, veículos explícitos das [suas] intenções ético-estéticas” (MORAES, 1997 p. 194) e exercita teoria sobre seu próprio ofício, deixando, em registro escrito - fora dos domínios oficiais de sua obra literária -, suas posições e convicções pertinentes à criação, ao estilo, às filiações e leituras. Na outra, é o homem a falar de si, das anedotas do cotidiano, das questões de seu espaço-tempo e a comunicar afetividade. Nesse sentido, produz autobiografia, na medida em que o faz de próprio punho, movido por sua própria vontade e em nome das relações de amizade.

Cito, a seguir, um trecho da correspondência de Mário com Carlos Drummond de Andrade. Trata-se de momento ainda inaugural na interlocução entre eles, quando Mário ainda está prestes a tomar conhecimento da grandeza poética que prometia um neófito Drummond, do alto de seus
20 anos de idade. Ele, por sua vez, ainda está vagamente deslumbrado com o fato de estar diante do profeta do modernismo paulista. Na passagem transcrita, Mário comenta os primeiros versos de Drummond a ele enviados, comparando-os com a prosa do escritor, de que já havia tido uma pequena vista com o artigo escrito por Drummond sobre Anatole France - para Mário, um ícone "passadista", ainda que guardada a sua importância:

Estou exausto e ainda não falei nos seus versos...Gostei. Gostei francamente, embora a sua prosa por enquanto seja mais segura que os seus versos. No entanto a prosa é mais difícil que a poesia. É muito simples: a sua prosa vem da civilização que morreu com a guerra. Você ainda é muito civilizado antes-da-guerra, pra cair de chofre no primitivismo deste século 20 que provocou o lirismo de certos alemães, russos e franceses atuais. Isso é natural. Estou me lembrando daquela frase que escrevi no prefácio da Pauliceia: "Ninguém se liberta duma vez das teorias avós que bebeu." Comigo se deu a mesma coisa. Pauliceia é uma mistura de simbolismo até parnasianismo, e modernismo que ninguém aqui percebeu porque, Deus dos justos! os críticos de poesia do Brasil [...] Eu tomei o partido de escrever em prosa simplesmente, no meio dos versos, como aquele comentário inteligente ( $=\mathrm{da}$ inteligência) que vem das "Danças", ou o caso do coronel Leitão do "Norturno". Ou então metrifico ("Rola Moça”) pra não cair no verso prosaico. 
[...] "Política", "Construção", "Religião", "Nota social", "Sentimental" são muito, muito bons. O "Orozimbo" é simplesmente admirável. [...] No "Orozimbo" a piada do fim, não sei, não gosto muito disso. Tenho a impressão de que você escreveu aquilo só pra acabar. [...] Como pratico com o Manuel Bandeira e o Luís Aranha, e eles comigo, mando-te os teus versos com algumas sugestões. Mas quero eles voltem pra mim. Preciso deles em minha casa enquanto não se publicam [... (FROTA, 2002, p. 72)

No trecho, Mário dá a entender que a poesia é ofício para Drummond e para muitos, como o foi para o próprio Mário - que exige maior tempo de maturação da parte do poeta: uma concepção horaciana de poesia. Em se tratando de Mário, é possível argumentar que o caminho foi, na prática, inverso àquele que ele considera ser o trilhado por Drummond, para o qual o amadurecimento da prosa ocorreu antes do da poesia. Esse parece ser o caminho mais natural, tradicionalmente feito pela maior parte dos escritores que podem arrogar-se os títulos de prosadores $e$ poetas, ou poetas que também produzem prosa com desenvoltura.

Mário, ao contrário, vai da poesia para a prosa. Não se trata de uma questão temporal - por ter se lançado ele, primeiro, como poeta, e pela ênfase que a dita "primeira fase" do modernismo brasileiro deu à poesia, de que Mário foi protagonista. Trata-se de uma constatação sobre sua persona literária, a que muitos textos e paratextos de Mário dão base. De qualquer maneira, ele já havia desbravado com louvor os domínios da poesia, que parece ter sido sua prioridade e primeira vocação, em obras como Há uma gota de sangue em cada poema, sua estreia como poeta, em 1917; Pauliceia desvairada, de 1922; Losango cáqui, de 1926; Clã do jabuti, de 1927; Remate de males, de 1930; e Lira paulistana, de 1946, livro póstumo. No entanto, a análise da personalidade e da trajetória intelectual de Mário de Andrade, somada aos subsídios que sua correspondência pessoal oferece para a "invenção" de sua identidade biográfica e literária (SOUZA, 2002, p. 105), permitiria concluir que a obra de ficção em prosa, pretendida como a obra-prima, agregaria à sua relevância como escritor, no Brasil, um coeficiente de popularidade e comunicabilidade. Como é consensualmente aceito, um dos predicados da forma prosaica, comparativamente à poesia, é sua maior referencialidade e limpidez. Assim, a realização no âmbito da poesia, com a verticalidade e significados cifrados próprios desta, normalmente não granjeia ao escritor a simpatia de um grande público. Mário, possivelmente ciente disso, e acalentando com ardor o desejo de ser uma expressão literária a ocupar o "lado esquerdo do peito" dos leitores - e tal desejo de palatabilidade está em perfeita sintonia com o ideal modernista -, vê, na composicão de uma obra em prosa nos moldes de um romance, o seu passaporte para a perenidade. 
A hipótese que defendo por ora é, pois, a de que a prosa de ficção escrita pelo poeta, muitas vezes - como parece ser o caso de Mário -, reflete uma busca por falar a um público maior, transcendendo os redutos ditos "privilegiados" (e empoeirados) em que se confinam os leitores do texto poético. Explico e exemplifico.

Mário, em carta a Luís da Câmara Cascudo de 26 de setembro de 1924, ao fazer o elogio entusiasmado do livro de Cascudo, Histórias que o tempo leva, de 1924, afirma:

O que mais atrai nos seus escritos deste livro, e mesmo no Joio [livro de 1924], Luís da Câmara Cascudo, é a sua despreocupação da literatura. Não há esse preconceito de fazer literatura que é a maior praga da arte de escrever. Nada de frases bem acabadinhas, ritmos preconcebidos, adjetivos para em [cantar; linguagem direta, pessoal, enérgica, simples, [eficaz. Mui] to bem. Admiro o seu livro. Creia que sou si[ncero e não te]nho a mínima intenção de lhe ser agradável. Nem me importam teorias, modernismos etc quando aprecio ou renego. [...] Não será mesmo essa a maior conquista dos modernos? Creio que sim. A literatura (mau sentido da palavra) nasceu no séc. XIX Nós conseguimos (alguns) libertamo-nos da literatura. Isso vai aos poucos naturalmente. Gosto sempre de fazer exemplo comigo mesmo, porque assim não parece que estou a atacar ninguém. Fui recheado de literatura. Reagi. Revoltei-me. Chamaram a isso de futurismo. [...] Pauliceia ainda está recheada de literatura na sua parte poética. Há muito parnasianismo, muito simbolismo, muita ideia literária oculta lá dentro e que como era de esperar passou despercebida aos críticos. Valeu como revolta (MORAES, 2010, p. 38).

Aqui, o poeta Mário de Andrade dá a conhecer seu incômodo com a chamada "literatura", entendida como cacoete do hermetismo ou do beletrismo. Seu combate ao ranço parnasianista na literatura brasileira, o "colarinho duro", a grandiloquência, a artificialidade, na poesia, rende o estudo-manifesto A escrava que não era Isaura, primeiro publicado na revista Estética, em 1925. Nele, o escritor dá segmento ao projeto de revolução estética modernista, discutindo aspectos bastante particulares da forma poética e rebatendo as críticas de futurismo a seu ideal estético.

O afã modernista por devolver à língua portuguesa o seu "brasileirismo", a brejeirice e a espontaneidade e pela destituição do tema poético nobre, o aproxima do prosaísmo, da fluidez e sobriedade características da forma prosaica. Esta, por sua vez, guarda uma relação direta com o discurso, a oralidade, a fala corredia, atravessada por erros e descontinuidades. Por outro lado, é primado da poesia o ritmo, atributo mais imediato de qualquer linguagem. Para Octavio Paz, o ritmo é
EM TESE
BELO HORIZONTE
v. 19
N. 1
JAN.ABR. 2013
CAMPOS. A prosa de Mário de Andrade, poeta
P. $140-160$

\section{Ensino e Teoria}


condição do poema, ao passo que é inessencial para a prosa. Pela violência da razão as palavras se desprendem do ritmo; essa violência racional sustenta a prosa, impedindo-a de cair na corrente da fala onde não vigoram as leis do discurso e sim da atração e da repulsa. [...] Deixar o pensamento divagar, é regressar ao ritmo [...]. O prosador, porém, busca a coerência e a claridade conceptual. Por isso, resiste à corrente rítmica à qual fatalmente tende a se manifestar em imagens e não em conceitos (PAZ, 1982, p. 82-83).

Para Mário de Andrade, uma apropriação infeliz da poesia levou a um desvirtuamento de suas qualidades originais:

Invejoso e macaco o primeiro homem resolveu criar também. E como não soubesse ainda cirurgia para uma operação tão interna quanto extraordinária tirou da língua um outro ser. Era também - o primeiro plágio! - uma mulher. Humana, cósmica e bela. E para exemplo das gerações Adão colocou essa mulher nua e eterna no cume do Ararat. Depois do pecado porém indo visitar sua criatura notou-lhe a maravilhosa nudez. Envergonhou-se. Colocou-lhe uma primeira coberta: uma folha de parra. [...

E cada nova geração e as novas raças sem tirar as vestes já existentes sobre a escrava do Ararat sobre ela depunham novos refinamentos no trajar. Os gregos enfim deram-lhe o coturno.
Os romanos o peplo. Qual lhe dava um colar, qual uma axorca. Os indianos, pérolas; os persas, rosas; os chins, ventarolas (ANDRADE, 1980, p. 201-202).

Os excessivos atavios e polimentos que recebeu adulteraram sua nudez primeira, e, podemos dizer, fizeram-na perder-se de sua natureza - ritmo puro. Desse modo, os "punhos de renda" da erudição - e da falsa erudição - afastaram a poesia da linguagem falada, transformando-a em produto asséptico para consumo autista de alguns pedantes. Como definiu certa vez Rubem Braga, "não é por turvar-se a superfície que as águas são mais profundas”, e Mário de Andrade, na década de 1920, estava consciente de que a poesia passou a pecar por um excesso formal vazio e despropositado, com o único objetivo de gerar uma falsa complexidade que distraísse o leitor da falta do que dizer ou da total inabilidade poética daquele que escrevia.

Talvez seja neste momento em que a poesia torna-se "propriedade" da cultura erudita, que a mantém encarcerada pela forma errônea como foi largamente praticada e entendida.

A atração dos modernos para a prosa - e a de Mário de Andrade - pode ter-se dado, então, em virtude dessa necessidade de desconstruir o monolito sagrado em que a poesia havia sido convertida, para que a comunicabilidade e a maleabilidade da língua pudessem ser resgatadas.

\section{Ensino e Teoria}


Mário, em carta de 5 de agosto de 1923 a Manuel Bandeira, em que comenta, consultado por este, a forma ortográfica adotada para o termo "chouteira" no poema "Os meninos carvoeiros”, de O ritmo dissoluto (1924), sentencia:

"E vão tocando os animais uma chouteira enorme". Primeiro: ainda não consegui descobrir se escreveste chouteira ou chouteria. As duas vezes que caligrafaste a palavra fizeste- $\mathrm{o}$ de tal forma que por mim não pude resolver da colocação do erre. Entendi o verso doutra forma, que os meninos tocavam os animais e que estes caminhavam num chouto pesado. Vejo agora que a tal palavra queria significar o açoite de que os meninos se serviam. Acho que deves substituir o termo. Ninguém poderá jamais compreender tua intenção, pois, além de inventares um termo, dás-lhe um sentido que as fontes não autorizam. Sê tradicional. Hoje estou nisto. Vê minha crônica no número de agosto da Revista do Brasil. Vê mais o trecho da Escrava que sairá no número de setembro da América Brasileira. Verás nelas o que penso sobre o tradicionalismo e sobre o hermeticismo. Sei muito bem a repugnância que nos dá, a nós - poetas de nós, qualquer concessão feita aos outros. E essa concessão é necessária, entretanto. Hoje sou muito humilde. Meu maior desejo ser homem entre os homens. Transfundir-me. Amalgamar-me. Ser entendido. Sobretudo isso. QUERO SER ENTENDIDO. Porque se verdade que Deus me deu alguma coisa de superior, é num desejo que os outros beneficiem dessa coisa. Não me atrai a volúpia de ser só. Aceito o que me dão e dou-me em troca [...] (MORAES, 2001, p. 101. grifos meus)

Aqui, Mário, ao sabor de um de seus inúmeros arroubos epistolares, manifesta um forte desejo por comunicar-se, ser entendido, para além de ser "poeta de si", ou falar apenas para si mesmo ou para sua tertúlia literária. Por meio da prosa de ficção, portanto, uma vez que o discurso poético passou a repelir, historicamente, o leitor médio, ordinário, o escritor poderia coroar seu ideal por falar ao homem brasileiro que tanto buscava entender.

Não pretende este texto, pelo dito, endossar a mistificação da superioridade da poesia sobre a prosa, ou estereotipar o público-leitor de uma e de outra. A poesia - é preciso assim reconhecer - define-se pela busca de verticalidade, de profundidade e essência, de nomeação do que é sem nome, inefável, não necessariamente visível ao olho nu de todo dia. Ela possui forma própria - por vezes, detém-se na dimensão do significante -, estiliza a língua, não se acomoda nas convenções, ao provocar novos sentidos e desbravar caminhos não habituais de leitura do mundo. Sendo dotada dessa natureza, é concebível que a entrada no texto poético exija uma maior disponibilidade de tempo, com boas doses de contemplação - hábito que, na contemporaneidade, está perto da extinção -, uma familiaridade maior com a língua, para que, quando desafiada, seja inteligível ao leitor. Ademais, a poesia exige 
a aceitação do não entendimento pela via da razão, das lógicas limitantes de uma sociedade tecnocrata, mais construída pela repetição que pela criação. Asseverar, entretanto, que a leitura de poesia requer um conjunto mais sofisticado de habilidades cognitivas deve-se, em grande parte, à deturpação a que aludi anteriormente, na qual a poesia foi desviada por caminhos que a roubaram de um público maior.

Naturalmente, a poesia surge antes da prosa, e houve tempo suficiente para que a imagem do poeta também fosse alvo dessa mistificação, traduzida pelo Romantismo, que surge em fins do século XVIII na Alemanha, na figura do poeta-profeta, vate, emissário, "antena da raça". Embora a estética do gênio tenha existido desde a Antiguidade Clássica (com os aedos, cantores, ou contadores de histórias, considerados "emissários divinos", e, a partir de Aristóteles, com eram seres de exceção, melancólicos - políticos, filósofos e poetas), a estética romântica cristaliza a imagem do poeta como a de um ser que fala uma língua superior, por vezes inapreensível porque, ao veicular seu próprio tempo-espaço, enxerga além dele.

A prosa, por sua vez, ganha associação com a razão cartesiana, linear, lógica. É a fala institucional, referencial, transparente, por meio da qual fala o Estado. Espelha o banal, o cotidiano, o superficial (o próprio adjetivo prosaico é relacionado ao baixo, comezinho, sem importância, ordinário, e, no dicionário Oxford, que contém significados históricos, recebe a denominação de "não romântico" durante o século XVIII, não por acaso, auge do Romantismo).

Reconhecida as naturezas atribuídas a cada uma - prosa e poesia - não se pode, no entanto, naturalizar esse esquema. Sabemos que a obra de arte moderna no século XIX só é possível, entre outras coisas, pelo tratamento sublime dado ao prosaico, ao cotidiano e ao detalhe insignificante. Além disso, parece mais razoável - e com mais oportunidades de sucesso - pensar em prosaico e poético como propriedades que atravessam a linguagem, podendo estar presentes em quaisquer textos, independente de sua forma imediata. Corroborando essa compreensão, Susan Sontag, em "Uma prosa de poeta”, no qual reflete sobre como a mistificação da superioridade da poesia sobre a prosa incide fortemente sobre a geração que fez aquela que é conhecida como Idade da Prata da literatura russa - com uma insigne safra de poetas - cita aquele que é um de seus exemplares ilustres, Joseph Brodsky: “[...] o poeta, em princípio, é “mais elevado” do que o prosador [...] porque um poeta carente de dinheiro pode sentar-se e redigir um artigo de jornal, ao passo que, um apuro do mesmo tipo, um prosador dificilmente pensaria em escrever um poema." Contudo, para Sontag, a questão crucial a ser entendido acerca do abismo cavado entre prosa e poesia não diz respeito ao fato de que "escrever poesia é um

\section{Ensino e Teoria}


trabalho mais mal remunerado do que escrever prosa, mas sim em que é algo especial - a marginalização da poesia e do seu público; aquilo que no passado foi visto como uma capacidade normal, como tocar um instrumento musical, agora parece a esfera do difícil e do intimidador" (SONTAG, 2005, p. 17).

No que concerne ao poeta Mário de Andrade, ainda que soe por demais ousada esta afirmação, é em sua prosa de ficção que transparece aquela que, por vezes, coloca-se como uma "incapacidade" do escritor de se destituir de projeto aparente vício da literatura brasileira aludido no início deste ensaio. A fabulação mais pura concretizar-se-ia, em definitivo, para Mário de Andrade, em um olímpico romance. Este, guardado pela tradição como a realização mais alta e monumental da forma prosaica, levaria Mário à consagração como escritor, e escritor somente, inscrevendo-o na galeria em que já havia se colocado, por exemplo, o amigo e interlocutor Carlos Drummond de Andrade. Embora Mário tenha realizado bem-sucedidos trabalhos em prosa - com um colosso de críticas, ensaios e artigos sobre literatura, música, arte e folclore, em que merecem destaque o projeto da Enciclopédia Brasileira (1939) e o livro ensaístico Namoros com a medicina (1937) - e em prosa de ficção - com os contos de Primeiro an dar, de 1926, e Contos de Belazarte, de 1934; o romance Amar, verbo intransitivo, de 1927 e Macunaíma, rapsódia, de 1928 realização definitiva como romancista, livre dos cacoetes "modernosos" e do "hábito" da tese, permaneceu em aberto, como revela a leitura de Amar, verbo intransitivo (com o "falar errado" intencional, a discussão de teorias literárias e críticas de obras de arte), de Macunaíma (tese) e Quatro pessoas, de 1938 , romance inacabado (tese).

A seguir, teço comentário sobre estas duas últimas reali-

\section{QUATRO PESSOAS E MACUNAÍMA: O PROBLEMA DA TESE}

O compromisso é evidentemente demasiado forte, mesmo quando aquele que se pretendia o ficcionista em Mário de Andrade entra cena. Como revelam duas de suas obras - a primeira, certamente a mais célebre e emblemática, Macunaíma, o herói sem nenhum caráter (1928) - e a segunda - Quatro pessoas (1938) -, a ficção marioandradina é tímida, isto é, não desobrigada da necessidade de pesquisar o caráter nacional, levanta um voo que se poderia dizer "rasante", a despeito do sincero esforço de um aplicado Mário.

A literatura é usada como instrumento para civilizar o Brasil, indagar a respeito de sua formação histórica, propor reflexão sociológica e elaborar teses que possivelmente contribuíssem para a compreensão de um país ainda incógnito para os seus. Não por acaso, ser o bastião cultural da modernidade no Brasil soma-se à necessidade do "arame" para viver. zações em prosa de ficção de Mário de Andrade.

\section{Ensino e Teoria}


Mário buscou estar no exercício direto de seu ideal, sobretudo, quando ocupa o cargo de diretor do Departamento de Cultura de São Paulo, no qual pôde desenvolver seu projeto em pesquisas folclóricas e colocar-se como formulador de políticas culturais que pretendiam atingir as camadas menos privilegiadas da sociedade. Além disso, faz militância estética nas inúmeras publicações periódicas para as quais contribuiu - que se encarregavam da divulgação do projeto modernista - e em sua correspondência pessoal.

Guardada a importância de Macunaíma para a literatura brasileira, com a sintonia com a renovação estética empreendida pelas vanguardas, e para a consolidação do estatuto da modernidade no Brasil a partir de uma tomada de consciência da ausência de um caráter na cultura e no homem brasileiro, representada no personagem de Macunaíma, o livro não existe como ficção independente - ou "caso inventado", nas palavras de Mário - e dificilmente pode ser lido de forma descontextualizada, sem evocar os muito particulares caminhos da formação histórica, social e cultural do Brasil. No processo de composição, Mário procedeu de modo a criar uma mistura de elementos culturais tipicamente brasileiros, ou seja, ligados às muitas e diversas tradições populares que povoam o celeiro cultural brasileiro, as quais ficaram silenciadas sob as tradições do homem branco. Para lograr o que pretendia com a obra, Mário se serve das inúmeras viagens que fez pelo Brasil, conforme o propósito modernista de desvendá-lo. Em carta de 1 de março de 1927 a Luís da Câmara Cascudo, o escritor assim explica o empreendimento:

Não sei se te contei ou não mas em dezembro estive na fazenda dum tio e...escrevi um romance. Romance ou coisa que o valha, nem sei como se pode chamar aquilo. Em todo caso chama-se Macunaíma. É um herói taulipangue bastante cômico. Fiz com ele um livro que me parece não está rúim e sairá em janeiro ou adiante, do ano que vem. Minha intenção foi esta: aproveitar no máximo possível lendas tradições costumes frases feitas etc. brasileiros. E tudo debaixo dum caráter quase sempre lendário porém como lenda de índio e negro. O livro quase que não tem nenhum caso inventado por mim, tudo são lendas que relato. Só uma descrição de macumba carioca, uma carta escrita por Macunaíma e uns dois ou três passos do livro são de invenção minha, o resto tudo são lendas relatadas tais como são ou adaptadas ao momento do livro com pequenos desvios de intenção. [...] Um dos meus cuidados foi tirar a geografia do livro. Misturei completamente o Brasil inteirinho como tem sido minha preocupação desde que intentei me abrasileirar e trabalhar o material brasileiro. Tenho muito medo de ficar regionalista e me exotizar pro resto do Brasil. Assim lenda do Norte botei no Sul, misturo palavras gaúchas com modismos nordestinos ponho plantas do Sul no Norte e animais do Norte no Sul etc. etc. Enfim é um livro bem ten- 
denciosamente brasileiro (MORAES (Org.). Câmara Cascudo Mário de Andrade - cartas, 1924-1944, p. 123).

Trata-se, como definiu o próprio Mário, de uma coletânea de lendas e costumes brasileiros, o que dá a estrutura de uma rapsódia, e não de um romance, como ainda hoje é erroneamente referido. A escolha de tal gênero, ao lado da intenção confessa em sublinhar um aspecto brasileiro, significativamente revela um voltar-se da obra para fora, em que a invenção literária - embora naturalmente ela não possa ser negada na obra, já que existe uma manipulação criativa na maneira como os traços culturais são arranjados - parece não ser a tônica, nem mesmo a prioridade. Do ponto de vista da criação, Macunaíma é exemplar da obra comprometida com a representação - e demonstração, de forma satiriza$\mathrm{da}$ - da realidade, caso interessante do excesso de projeto do vezo de explicar e teorizar a realidade, sem afirmação da independência criativa da literatura em mergulhar em seu próprio mundo - e buscar outros.

Quatro pessoas, por sua vez, é um romance - ou, a bem dizer, um projeto de romance - bastante sugestivo da dificuldade, por assim dizer, em levar a bom termo a intenção de produzir uma obra interessada unicamente em "contar uma história”. Em 1938, Mário pede demissão da chefia do Departamento de Cultura de São Paulo e se muda para o Rio de Janeiro, onde assume o cargo de professor na Universidade do Distrito Federal. É quando dá início à escrita do livro - proposta de "estudar por meio de dois amigos íntimos a doutrina de Marañon sobre ser o verdadeiro macho o que se fixa em amar uma fêmea só" (ANDRADE, 1986, p. 35). O texto, que se constrói em torno de quatro personagens - dois casais -, nasce como um projeto glorioso de uma espécie de romance psicológico, no aparente intento de usar o fluxo de consciência como procedimento romanesco, ou mesmo de realizar o texto com um narrador em onisciência que "não fosse o próprio Mário”. O resultado, como se pode verificar à medida que progredimos na leitura do texto, é um desajeitado "meio do caminho" entre os dois processos: a análise psicológica é feita sem a técnica madura; as personagens não têm voz, o que fica evidente na carência de diálogos; o narrador é entidade massacrante e inoportuna, que conduz o romance à rédea curta, de modo que o texto não ganha ritmo e fluidez. Por fim, o narrador não é uma instância textual, mas o próprio mal disfarçado Mário de Andrade a falar, com o brasileirismo linguístico por que se celebrizou, presente com a mesma pretensa naturalidade tanto nos textos de verve poética quanto em sua correspondência. Essa constatação ecoa a assertiva de Sontag sobre a prosa de poeta: "A prosa de poeta é, sobretudo, sobre ser poeta [...] O eu mencionado é o eu do poeta" (SONTAG, 2005, p. 20).

\section{Ensino e Teoria}


2. Para uma melhor perspectiva das ressalvas feitas ao romance de Mário, ver a edição crítica de Maria Zélia Galvão de Almeida (1985), na qual consta, além do omance anotado, o projeto ou esquema original de Mário de Andrade para a obra.
É provável que o próprio Mário estivesse ciente de tais problemas, já que abandonou a escrita do romance em 1943. Nas passagens a seguir, é possível ter uma amostra da pouca expressão nas falas das personagens: ${ }^{2}$

Deixou os braços desalentado, num gesto de juvenilidade graciosa, vagamente feminina. Abaixou o rosto para o lado, num desamparo infeliz, um daqueles seus gestos instintivos, sem nenhum cálculo, em que de tal forma se misturavam nele uma eterna juvenilidade perdoável e o trágico do homem forte ferido, que era ao mesmo tempo drama e esplendor, invencível. Confessou:

- Eu gosto muito dela, sim... [...]

Estava terrível de ver, e em sua beleza delicada e grave, havia todo um desmanchamento de traços numa expressão que não chegava a ser de dor, não chegava a ser de fadiga, era indistinta, quase agressiva, mas em que se estampava um sinal de voluptuosidade, incorreto, baixo, espasmódico. Carlos ficou horrorizado.

- Maria, o que 'ocê tem! você está cansada, não!...e segurou-a pelos braços the soerguendo um bocado o busto, que ela largara sobre as ancas, acentuando ainda mais a sua incorreção de mulher um bocado baixa (ANDRADE, 2005, p. 78 e 80).

Pela leitura da correspondência de Mário, é possível acompanhar seu progresso na escrita do romance, até o esmorecimento total do projeto. O escritor partilha, em especial com Oneyda Alvarenga, informações sobre a obra inconclusa, quando do sopro inicial de sua criação. Em carta de 19 de março de 1939, Mário diz estar "com um romance engatilhado faz duas semanas" e mostra-se ansioso por levá-lo a cabo, sem, contudo, encontrar tempo para fazê-lo. Vejamos:

Oneida, recebi hoje o embrulho das conferências e a nova carta. Já tinha recebido a outra, sim, mas ficara até agora sem resposta por causa do trabalho. Hoje mesmo passei estudando a tese do [...] pro concurso de Folclore que principia amanhã e de que sou um dos examinadores. [...] Acabei ontem uma das minhas reformas pedidas pelo Capanema, mas não irei descansar. Dia 10 próximo principiam as aulas da Universidade e confesso que é com melancolia que vejo se aproximar essa caceteação. (....) Depois agora tenho muito mais trabalho, com pelo menos dois artigos a escrever por semana, e um deles de crítica literária, pro Diário de Notícias, o que me obriga e ler muito. A vida continua encarcerada, como se vê, mas com uma leve esperança de milhorar financeiramente, pois estou em véspera de pagar minhas dívidas, com que venho há quase um ano me esgrimindo. Como é pau dever!

[...] estou com um romance engatilhado faz duas semanas e não acho jeito de o principiar, tal o trabalho. E me parece pena porque gosto dele. Mas quem jamais não achou lindo o filho
EM TESE
BELO HORIZONTE
v. 19
N. 1
JAN.-ABR. 2013
CAMPOS. A prosa de Mário de Andrade, poeta
P. $140-160$

\section{Ensino e Teoria}


que vai nascer! E é só. Pretendia escrever só deum lado do papel, pois estou aproveitando esta noite e a guarda dominical do Senhor pra dar conta de uma coluna de cartas. [...] (ALVARENGA, 1983, p. 182-183).

O trecho dá a ver modelarmente a realidade de um Mário polivalente, em alguma medida obrigado a sê-lo pela necessidade do "arame" para viver, mas também escolhendo de bom grado (e com algum inconfessado prazer, embora diga o contrário) o desempenho de funções diversas, por meio das quais lhe foi possivel colocar em exercício uma versatilidade que ao tudo indica, ser-lhe-ia difícil de conter.É o retrato do intelectual modernista, que relembra-nos da "urgência em realizar o balanço do projeto estético e político do Modernismo, a par de evidentes contradições assumidas pelo intelectual dividido entre um projeto coletivo de cultura e o individualismo artístico" (SOUZA, 1999, p. 193), aspecto flagrante na carta referida. Nela, Mário menciona ter terminado "as reformas pedidas pelo Capanema”, numa referência ao pedido que lhe fez o então ministro da Educação e da Saúde, Gustavo Capanema, em 1936, para que elaborasse um anteprojeto de lei para a preservação do patrimônio cultural brasileiro. Mário, naturalmente, não foi o único a tomar parte na esfera política. Outros intelectuais como Manuel Bandeira, Heitor Villa-Lobos e Rodrigo Mello Franco Andrade colaboraram como consultores, formuladores ou defensores de propostas educativas de programas do governo (IPHAN, 2013). Entre esses nomes, destaca-se ainda o de Carlos Drummond de Andrade, chefe de gabinete de Capanema durante todo o período de sua gestão (1934-1945).

O insucesso dessa empreitada, em particular - e da obra de ficção em prosa de grande fôlego, o romance - pode estar ligado, entre outras coisas, com a dificuldade do escritor em função do sem número de atividades que acumulava - de encontrar disponibilidade de tempo para a imersão de que a escrita que um texto dessa natureza requer. Esse desejo - o de escrever um romance, ou coisa que o valha, aparentemente, não era exclusivo a Mário. Outros poetas, como Manuel Bandeira, também o manifestaram. A diferença essencial entre a produção de poesia e de prosa parece residir na questão da gestão do tempo: enquanto a arte poética - poema a poema - acontece normalmente de forma amiudada, espaçada, e assim também o próprio conto, ao lado de outras formas curtas em prosa, como a crônica e o ensaio, e o ideal é que os intervalos em sua confecção não sejam longos; do contrário perde-se "o fio da meada", e a cadência do texto pode ser comprometida.

No trecho citado a seguir, Mário de Andrade medita sobre o tema, a propósito da progressão de Quatro pessoas, e corrobora essa visão: 
Oneida

Estou com preguiça de escrever à máquina mais hoje. Batia máquina o dia inteiro e avancei inesperadamente doze páginas no meu romance que não há meios de avançar, tempo não chega. Estou apenas na p. 27, tipo ofício, datilografado, isto é pra aí umas 50 páginas de impressão. Acabei o I capítulo. Não sei se estará bom, é uma coisa louca, uma análise psicológic feroz. Duvido que alguém aguente e, o pior, duvido que seja qualquer coisa de bom. Mas é desses livros que o milhor, se acabar, é não pedir a opinião de ninguém, ou publicar ou destruir, mas por conta própria, sem me garantir de ninguém. Estou numa inquietação horrível, e isso ainda maltrata mais o avanço do livro, porque quando penso em escrever me sinto sem força, sem coragem pra perder tempo com uma possível borracheira longa. Um poema, até um conto, ainda a gente não se inquieta de escrever e jogar fora, mas um romance inteirinho, é horrivel, minha amiga (ALVARENGA, 1983, p. 191).

Num primeiro momento, a ingenuidade nos leva a crer ter escapado a Mário a clarividência sobre suas limitações como ficcionista, e essa passa a ser, para nós, a sua "pequena tragédia". Entretanto, trechos como o transcrito a seguir extraído da crônica "Começo de crítica", publicada no Diário de Notícias do Rio de Janeiro em 5 de março de 1939, contrariam nossas expectativas, ao mostrar um Mário duramente lúcido:
É certo que, como já acentuaram amigos meus e críticos, a parte da ficção da minha obra se prejudicou bastante pelos utilitarismos em que voluntariamente a escravizei, as teses que pretendi provar, os problemas que repus na ordem do dia. Às vezes, nos momentos de fraqueza ou vaidade, me umedece por causa disso um certo limo de melancolia, mas logo retomo a ordem que me enrija o espírito e o prejuízo não dói mais. Tenho muito consciente conhecimento das minhas forças para sabe que não me condena à glória nenhuma espécie de fatalidade. Por mais livre que fosse a minha ficção, jamais ela alcançaria as alturas de um Murilo Mendes, de um Manuel Bandeira, de um Lins do Rego, Raquel de Queirós ou Amando Fontes [...]. Nem sequer uma longa paciência me faria alcançar as alturas desses e outros grandes. Mas em compensação tenho a forte alegria de reconhecer que meus livros de ficção tiveram sempre o efeito que lhes dei por destino. Só me decepcionaram um bocado certos virtuosismos de má morte, como o romance do "Rola Moça”, o "Acalanto do seringueiro" e poucos mais, obras de sentimentalismo fácil que uma honestidade mais atenta não me permitiria publicar. [...]

Outra obra que me deu desgostos foi o Macunaima. Sinto que tive nas mãos o material de uma obra-prima e o estraguei. Fazendo obra sistematicamente de experimentação, jurei no princípio de minha vida literária jamais não me queixar das incompreensões alheias. Acho ridículos os incompreendidos. Mas, por uma só vez, me seja permitido afirmar que esse

\section{Ensino e Teoria}


livro foi, no geral, apreciado por uma feridora incompreensão. Embora graciosa porém não complacentemente tratado, Macunaíma é uma sátira irritada, por muitas vezes feroz Mas brasileiro não compreende sátira, em vez, acha engraçado (ANDRADE, 1993, p. 12).

O texto, que inaugura a contribuição de Mário de Andrade para o Diário de Notícias carioca, em 1939, na coluna até então ocupada pelo escritor mineiro Rosário Fusco, tem sabor de antecipado epitáfio. Nele, Mário passa a limpo episódios incômodos, dignos de esclarecimento, em sua trajetória literária e pessoal, como sua adesão ao Partido Democrático - segundo Mário, mais por pressão dos amigos que por vontade espontânea -, e divaga sobre temas como Deus e a importância das obras de arte na existência humana.

O que nos interessa de perto e merece comentário na crônica, no entanto, como já referido, diz respeito à sua autocrítica como escritor de literatura, sobretudo como ficcionista. A consciência demonstrada por Mário sobre seu cacoete de produzir pensamento e "fazer tese", tendo o texto literário como pretexto, chega a ser desconcertante. Ele destaca Macunaíma como uma de suas experiências literárias mais frustrantes, já que a recepção da obra foi, segundo ele, marcada pela incompreensão. Deliberadamente um trabalho de "experimentação", Macunaíma pretendeu satirizar a falta de "caráter", isto é, de identidade na nação brasileira, constituindo-se um autêntico exemplar da "obra de tese". Para Mário, o "recado", contudo, perdeu-se nas entrelinhas.

Não se pode deixar de anotar, ainda, o espanto que Mário causa em seu leitor, sobretudo póstumo, ao afirmar a inferioridade de sua ficção - ainda que ela tivesse gozado da liberdade necessária para seu desenvolvimento - em relação a nomes como Murilo Mendes, José Lins do Rego e Manuel Bandeira (a menção deste surpreende particularmente, já que Bandeira não produziu ficção). Se pura retórica - captatio benevolentiae para angariar a simpatia do leitor - de um Mário sedutor, ainda assim, estamos diante de um dado, que, recolhido em um dos textos de sua obra como cronista, dá força à hipótese que vem sendo por ora explorada.

\section{CONSIDERAÇÕES FINAIS}

O projeto da obra de ficção definitiva, nos moldes de um romance, parece ter sido perseguido por Mário de Andrade, como permitem aventar momentos significativos de sua correspondência pessoal. Como observado, tal projeto jamais encontrou todas as condições necessárias à sua concretização. As prováveis causas teriam sido o tempo escasso do escritor, que se desdobrava em um sem número de tarefas relacionadas à sua militância cultural e à necessidade pessoal de trabalho remunerado, além de uma sugestiva dificuldade em se desvencilhar do hábito de produzir pensamento, tese, 
tendo o espaço da ficção como pretexto. Sobre os prejuízos dessa preocupação sistemática e excessiva, que naturalmente se justifica dentro da contingência histórica e cultural em que se insere Mário de Andrade, o escritor Isaac Bashevis Singer sintetiza: "A busca da mensagem fez muitos escritores esquecerem que contar histórias é a raison d'être da prosa artística” (SINGER, 2004, p. 16).

Por fim, fica visto de que forma a leitura da correspondência pessoal de Mário de Andrade reacende o interesse por recantos pouco explorados de sua obra literária - que ainda permanece eclipsada pela figura do formador do pensamento artístico-cultural de uma época -, por conter em si o avesso da criação, o "lado b" que nos permite entrar em contato com aquilo que o autor convenientemente "esqueceu", ou que não pôde comunicar a seu leitor no momento em que entregou a obra sob a forma de um produto comercializável (SANTIAGO, 2003, p. 15).

\section{REFERÊNCIAS}

ALVARENGA, Oneyda (Org.). Mário de Andrade-Oneyda Alvarenga: cartas. São Paulo: Duas Cidades, 1983

ANDRADE, Mário. A escrava que não era Isaura. In: Obra imatura. 3. ed. Belo Horizonte: Editora Itatiaia, 1980. (Obras completas de Mário de Andrade, I)
Quatro pessoas. Edição crítica de Maria Zélia Galvão de Almeida. Belo Horizonte: Itatiaia, 1985. (Coleção Buriti, 24)

Começo de crítica. In: SACHS, Sonia (Org.). Vida literária. São Paulo: Hucitec/Edusp, 1993. p. 11-16.

FROTA, Lélio Coelho (Org.). Carlos e Mário (correspondência de Carlos Drummond de Andrade e Mário de Andrade). Prefácio e notas de Silviano Santiago. Rio de Janeiro: Bem-Te-Vi, 2002.

NSTITUTO do Patrimônio Histórico e Artístico Nacional (IPHAN). Disponível em: < http://portal.iphan.gov.br/portal/ .

ESSI, Joaquim Maria. Instinto de nacionalidade. Nova Aguilar, 2000. v. 3

MICELI, Sérgio. Os intelectuais e a classe dirigente no Brasil (1920-1945). São Paulo; Rio de Janeiro: Difel, 1979

MORAES, Marco Antonio de. Carta, testemunho e biografia. In: AYALA, Maria Ignez Novais; DUARTE, Eduardo Assis (Org.). Múltiplo Mário. João Pessoa: Ed. Universitária UFPB/ Ed.

Universitária UFRN, 1997. p. 184-197.

(Org.). Correspondência - Mário de Andrade \& Manuel Bandeira. São Paulo: Edusp, 2001

(Org.). Mário, Otávio. Cartas de Mário de Andrade a Otávio Dias Leite. São Paulo: IMESP, 2006. Acesso em. 22 abr. 2013.

\section{Ensino e Teoria}


(Org.). Câmara Cascudo e Mário de Andrade - cartas,

1924-1944. São Paulo: Editora Global, 2010.

PAZ, Octavio. $\mathbf{O}$ arco e a lira. Trad. Olga Savary. Rio de Janeiro: Nova Fronteira, 1982. (Coleção Logos)

SANTIAGO, Silviano. O intelectual modernsita revisitado. In: Nas malhas da letra. São Paulo: Companhia das Letras, 1989. p. 165-175.

Com quantos paus se faz uma canoa. Arquivo

literários. São Paulo: Ateliê Editorial, 2003. p. 15-24.

A atração do mundo: políticas de globalização e

de identidade na moderna cultura brasileira. In:

cosmopolitismo do pobre. Belo Horizonte: Editora UFMG, 2004.

p. $11-44$.

SINGER, Isaac Bashevis. 47 contos. Rio de Janeiro: Companhia das Letras, 2004. p. 16

SONTAG, Susan. Uma prosa de poeta. In: ___ Questão

de ênfase. Trad. Rubens Figueiredo. São Paulo: Companhia das Letras, 2005

SOUZA, Eneida Maria de. Notas sobre a crítica biográfica. In:

Crítica cult. Belo Horizonte: Editora UFMG, 2002. p. 111-119.

\section{Ensino e Teoria}

